\title{
THOUGHTS ON FRIENDSHIP IN THE LETTERS OF Peter The Venerable ${ }^{\dagger}$
}

\author{
Marc Saurette, Carleton University
}

\begin{abstract}
I do not know where to begin. I am completely unsure of where to make a start. Dark clouds cover a bright day, a haze of fog clothes the sun's shining rays, the midday brightness unexpectedly takes the appearance of dreadful shadows. The nature of things is changed: sunrise is transformed into sunset, a roaring fire is quickly extinguished, the silver cord is severed, friend is estranged from friend. ${ }^{\mathrm{I}}$
\end{abstract}

The terrifying apocalypse Peter the Venerable fears to discuss with his confidant Hato of Troyes was not a new heretical sect or the spectre of a coming Anti-Christ, but rather the ghost of a chance that the "silver cord" of their friendship had been broken. ${ }^{2}$ Peter's vibrant image of approaching darkness underscores the significance he assigned to friendship as a social bond at the heart of the natural order. A world without friendship was the obverse of the world as it should be.

Such flowery protestations of friendship are not uncommon in Peter the Venerable's letters. The term amicitia appears just under fifty times and additional uses of amicus and its cognates number in the hundreds, underlying if not the importance of this theme then at least its pervasiveness. ${ }^{3}$ But Peter never dealt with the subject in detail or at any length. He has left only indications of his thinking -a praise or critique here, an allusion there - almost none of which are longer than a few lines. While these clues cannot be seen to construct a coherent theory of friendship, they are suggestive of the general rules and responsibilities that Peter the Venerable claimed to be integral to "true" Christian friendship. Friendship, for Peter, was multifaceted, hierarchical and performative.

Unlike the modern variety, medieval friendships were very public relationships, usually demonstrations of membership in a "co-operative union" as Gerd Althoff terms it. ${ }^{4}$ Lords routinely

\footnotetext{
${ }^{\dagger}$ I would like to thank Matthew Ponesse and Isabelle Cochelin for their helpful comments. ${ }^{2}$ Peter the Venerable, The Letters of Peter the Venerable, ed. Giles Constable, Cambridge, Massachusetts : Princeton University Press, ${ }_{96} 67$ (2 vols); here vol. I, p. 9, ep. 5; Vnde incipiam nescio. Unde exordium faciam, prorsus ignoro. Serenam diem tenebrosa nubila contexerunt, nitentes solis radios caligosi aeris fumositas obduxit, meridianus fulgor teterrimarum repente umbrarum faciem induit. Rerum natura mutata est; oriens in occasum conuersus est; ignis praevalidus subito extinctus est; funis argenteus ruptus est; amicus ab amico disiunctus est. This work is hereafter abbreviated as Letters; all references will be to the first volume unless otherwise noted. All translations into English are by the author - part of an ongoing project to translate the letters into English for the first time. Given the current lack of a translation and the general paucity of work done on Peter's letters, I have sought in this article to give the flavour of Peter's texts by providing much direct quotation.

${ }^{2}$ Peter makes this point explicit in his following letter (Letters, p. II-I3, ep. 6) when he writes again to Hato to underline that the "silver cord" he mentioned was not -as Hato had interpreted- Peter's indebtedness for Hato's gifts, but the bond of friendship.

${ }^{3}$ While anyone reading through Peter's letters cannot fail to note the omnipresence of the theme of friendship, a more quantitative reckoning is provided by a search of the Patrologia Latina's digital edition (pld.chadwyck.com). Peter's opera omnia enumerates forty-nine separate uses of amicitia in addition to the roughly 270 occurrences of amicus, amicabiliter, etc. This number ranks the amicitia terminology in Peter the Venerable's works as higher than the works of any other author printed in the PL. Almost all the references are found in Peter's letters: two uses are found in the De miraculis and a handful more in his treatises.

${ }^{4}$ Gerd Althoff, Family, Friends and Followers: Political and Social Bonds in Early Medieval Europe, trans. Christopher Caroll, Cambridge : Cambridge University Press, 2004, p. 67.
} 
entered into sworn friendships that were made concrete through rituals or, beginning in the twelfth century, through written contracts. Churchmen were hardly strangers to such formal alliances. Perhaps even more so than secular lords, religious leaders joined themselves in friendship to other bishops, abbots, lords or kings. These personal (but not private) relationships harnessed affectivity to ensure mutual support and to help realize common goals in a society lacking the institutional relationships that structure today's (Western) political culture. As a son of the powerful Montboissier family, Peter the Venerable could hardly have avoided a familiarity with the political friendships that arose between lay aristocrats. As abbot, Peter continued to be involved in the social and political world of his birth and well understood the bonds of co-operation underlying its order. One letter to his brother Pontius, for instance, records how he negotiated a "friendship and perpetual alliance bound by unbreakable oaths" between two of his other brother at feud. ${ }^{5}$ This formal bond of friendship is best understood as a background to Peter's thinking in his letters.

As we will see, Peter the Venerable's explicit statements about friendship give it both practical rules and an uplifting spiritual goal. In understanding it as such, he paralleled contemporary twelfthcentury models of friendship. A long history of theorizing had distinguished paradigms for friendship by Peter's time - some positive, some negative- and the perceived utility of these paradigms meant that they were followed. As C. Stephen Jaeger has persuasively argued, lay and clerical elites adhered to idealized models of virtuous friendship in order to demonstrate themselves to be the very thing that they claimed, that is, better than others. ${ }^{6}$ For example, a king might forego feud and publically kiss a former enemy in friendship; the goal was not to create an emotional bond (something seeming unlikely), but to demonstrate to the court that he was the very model of a forgiving Christian leader and thus above other nobles. The performance of the model, therefore, was a way of manufacturing status and projecting public identity. In this context, Peter's thoughts on friendship are not merely abstract musings or personal feelings, but indications of a behavioral model shared with his contemporaries.

Twelfth-century monasticism was heir to classical conceptions of civic virtue and Christian models of love when it came to friendship. Greco-Roman ideas -largely transmitted to the Middle Ages in condensed form by Cicero's On friendship- provided a terminology for amicitia focused on its mutual responsibilities, obligations and regulation. ${ }^{7}$ Certain books of the Old Testament (especially Sirach) offered similarly-oriented material, outlining injunctions about testing and maintaining fidelity in friendship. ${ }^{8}$ A mystical strand emerging from Hellenistic sources was transmitted and expanded in the

\footnotetext{
${ }^{5}$ Letters, p. 233, ep. 9I; sacramentis inuiolabilibus in perpetuum foedus amicitiamque iuratos.

${ }^{6}$ C. Stephen JAEGER, Ennobling Love: In Search of a Lost Sensibility, Philadelphia : University of Pennsylvania Press, 1999. As the title suggests, Jaeger argues throughout his study that medieval discourses of virtuous love and friendship belonged to the competition for status in courtly and religious society; for the example cited, see p. II-I3.

${ }^{7}$ For a discussion of Cicero's Laelius de amicitia, see David KONSTAN's Friendship in the Classical World, Cambridge : Cambridge University Press, 1997, p. I22-36 and its extensive bibliography (p. I77-97); for Cicero's currency in the Middles Ages, see Jan ZIOLKOWSKI, "Twelfth-Century Understandings and Adaptations of Friendship," in Medieval Antiquity, ed. Andries Welkenhuysen, Herman Braet and Werner VerbeKe (Mediaevalia Loavaniensia ser. I, stud. 24), Leuven: Leuven University Press, 1995, p. 59-8I and James MCEvoY, "The Theory of Friendship in the Latin Middle Ages: Hermeneutics, Contextualization and the Transmission and Reception of Ancient Texts and Ideas, From c. AD 350 to c. I5oo," in Friendship in Medieval Europe, ed. Julian HASELDINE, Thrupp-Stroud-Gloustershire : Sutton, 1999, p. 3-44. In particular, Ambrose's De officia repeats with a Christian twist the essence and at times the exact words of Cicero's thinking on friendship, see Carolinne Whiтe, Christian Friendship in the Fourth Century, Cambridge : Cambridge University Press, I992, p. III-I28.

${ }^{8}$ For ideas of friendship in the book of Sirach, see Jeremy CORLEY, "Friendship According to Ben Sira," in Der einzelne und seine Gemeinschaft bei Ben Sira, ed. Renate EGGER-WENZEL and Ingrid Krammer (Beihefte Zur Zeitschrift Für Die Alttestamentliche Wissenschaft, 270), Berlin-New York : de Gruyter, 1998, p. 65-72 or the collection of essays, Freundschaft
} 
Apophtegmata Patrum, as well as in the writings of Paulinus of Nola, Augustine and John Cassian. These works emphasized that human friendship was a reflection of a love for the divine and viewed friendship as an institution promoting Christian virtue. ${ }^{9}$

Classical and Late Antique traditions were nurtured in courts, cloisters and cathedral schools throughout the early Middle Ages, but historians argue that the twelfth century allowed for an unprecedented textual flowering of the elite discourse of friendship in monastic circles. ${ }^{\text {IO }}$ The popularity and utility of the theme of friendship led Aelred of Rievaulx to pen an definitive statement of the Cistercian model of friendship, De spirituali amicitia a few years after Peter the Venerable's death. While the text is often considered paradigmatic of this era in monastic friendship, historians have cautioned against seeing Aelred's ideas as any more universal to twelfth-century religious than Cistercian customs were. ${ }^{\text {II }}$ Peter the Venerable belonged to an earlier textual community shared by other Benedictines such as Anselm of Bec and Peter of Celle, who used letters to speak about friendship, or used friendship as a reason to speak, without making explicit and definitive formulations of their ideas. ${ }^{12}$

In this study, I will use Peter's letters as a means to suggest the ideas of friendship circulating in his literary orbit before the codification begun by Aelred and completed by Thomas Aquinas. ${ }^{\text {I3 }}$ Peter's statements about friendship should perhaps best be seen as 'rhetorical claims' because his letters give the impression that there are not definitive rules of friendship, only directives which are being negotiated by the correspondents. When compared, Peter's statements and restatements on friendship have one dominant purpose: they are used to establish and to compare the relative position of the letter writers. By speaking about the favours, the beliefs and the emotions shared by friends, Peter indicates the nuances in friendship which allow friends to be differentiated. This hierarchical conception of friendship, however, has been overlooked by historians, who have only tangentially considered what were medieval monastic conceptions of amicitia.

bei Ben Sira: Beiträge des Symposions zu Ben Sira. Salzburg 1995, ed. F. V. REITERER (Beihefte zur Zeitschrift für die alttestamentliche Wissenschaft, 244), Berlin - New York : de Gruyter, r996. For New Testament conceptions of friendship, there is a vast literature. Among the more recent is John T. FitzGERALD, "Christian friendship: John, Paul, and the Philippians," Interpretation 6I.3 (2007), p. 284-296 who notes two distinctive models of Pauline and Johannine friendship; George LYONS and William H, MALAS Jr. contextualize Pauline conceptions of friendship in light of Hellenistic traditions in "Paul and his friends within the Greco-Roman context," Wesleyan Theological Journal 42.I (2007), p. 50-69.

${ }^{9}$ For a general summary of Late Antique and early-medieval ideas of friendship, see Brian Patrick McGuIRE, Friendship and Community: the monastic experience, 350-125o (Cistercian Studies series, 95), Kalamazoo: Cistercian Publications, I988, chps. 2-5. Jean LeClerCQ (“L'amitié dans les lettres au Moyen Age," Revue du Moyen Age latin I [1945], p. 39I-4IO; here p. 4OI) notes that for Augustine the City of God was imagined as a societas amicalis - a community of perfect friends united in complete love of God and one another.

${ }^{\text {Io }}$ See MCGuIRE, Friendship and Community, p. xxix; see also the articles by H.M. Cantella, Courtney DeMayo, Constant Mews, Cary Nederman in the special issue of Viator $3^{8.2}$ (2007) devoted to the theory and practice of medieval friendship.

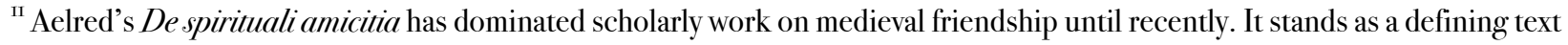
in McGuire's research, but traditional assumptions about Aelred's thought are increasingly questioned; see Jens RÜFFER, "Aelred of Rievaulx and the institutional limits of monastic friendship," Perspectives for an Architecture of Solitude: Essays on Cistercians, Art and Architecture in Honour of Peter Fergusson. ed. Terry KINDER (Medieval Church Studies, II; Studia et Documenta, I3), Turnhout: Brepols. 2004, p. 55-62 and Marsha DuTTON, “Aelred of Rievaulx on friendship, chastity, and sex: the sources," Cistercian Studies Quarterly 29.2 (I994), p. I2I-I96. Dutton's paper argues against a growing trend of finding homoerotic features in Aelred's writings.

${ }^{12}$ MCGUIRE, Friendship and Community, p. 209-13.

${ }^{13}$ Recent work has nuanced our understanding of Aquinas' theory of friendship as being more than a simple reception of Aristotelian ideas and shown his indebtedness to earlier medieval formulations; see especially Daniel SCHWARTZ, Aquinas on Friendship, Oxford - New York : Oxford University Press, 2007. 
Before I begin to consider Peter's writings I would like to make a few comments about what historians have said about Peter on the subject of friendship. Since the eighteenth-century, scholars have looked into Peter the Venerable's friendships, but have rarely considered what friendship is - at least to Peter. Beginning with Charles Clémencet's argument that Peter the Venerable's friendship with Bernard of Clairvaux led to the introduction of Cistercian customs to Cluny, historians of monasticism have used Peter's friendships to explain twelfth-century monastic reforms. ${ }^{I_{4}}$ In the last century, David Knowles, Jean-Baptiste Auniod, Ann Proulx Lang and more recently Brian Patrick McGuire revived and repeated the basics of Clémencet's argument, seeing Peter's flowery language of friendship as clear evidence of a man overcome by sincere emotion. ${ }^{15}$ According to this interpretation, Peter's love for Bernard flung open the Cluniac cloisters to Bernardine changes. Others, who are unconvinced that Cistercian ideas underlay the reform of Cluniac monasticism during the abbacy of Peter the Venerable, have denied the reality of the friendship, seeing Peter's declarations of friendship as empty rhetoric. ${ }^{16}$ While arguing against one another, both streams have inherited two shared bases from Clémencet. First, they often view Peter and Bernard less as persons and more as symbols of institutions. Second, the definition of friendship used to evaluate their relationship has tended to be anachronistic.

The first point has led scholars to conclude that the presence or absence of a real friendship signified the rapprochement or the continued hostility of the Cluniacs and Cistercians. The converse argument was also made, that if Cluniacs and Cistercians were not of the same mind, then Peter and Bernard could not be true friends. A modified version of this thesis was stated most recently by Gillian Knight, who sees in Peter's letters to Bernard of Clairvaux and to Hato of Troyes an intention to use the discourse of friendship to author his public persona as the voice of Cluny. ${ }^{\mathrm{I}}$

The existence of this literary presentation has important implications. By showing that personal and institutional identity are separate, Knight shifts the question of friendship from being about whether

\footnotetext{
${ }^{14}$ Charles Clemencet, Histoire littéraire de S. Bernard, abbé de Clairvaux, et de Pierre le Vénérable, abbé de Cluni, qui peut servir de supplément au 12e siècle de l'histoire littéraire de la France, Paris, I773. As Adriaan Bredero has shown, Clémencet's interpretation of this relationship was shaped by contemporary events in which the Maurists (Clémencet's order) belonged to a monastic ordo shared by themselves, the Strict Observance Cistercians and the Strict Observance Cluniacs. On this, see BREDERO's "Saint Bernard in his relations with Peter the Venerable," in Bernardus Magister, ed. John R. SOMMERFELDT (Cîteaux commentarii cistercienses, 42), Kalamazoo : Cistercian Publications, 1992, p. 3I5-347, here p. 3I6-I7; restated and updated in his Bernard of Clairvaux: Between Cult and History, trans. Reinder BruINSMA, Grand Rapids : W.B. Eerdmans, I996, p. $227^{-2} 3^{8}$.

${ }^{15}$ David KnOwLES, "Cistercians and Cluniacs. The Controversy between St. Bernard and Peter the Venerable. Inaugural Lecture Delivered at Cambridge in November 1954," in The Historian and His Character, and Other Essays, Cambridge : Cambridge University Press, 1955, p. 50-75; id., "The Reforming Decrees of Peter the Venerable," in Petrus Venerabilis 11561956, ed. Giles CONSTABLE and J. KritZECK (Studia Anselmiana, 40), Rome: Herder, 1956), p. 3-I2; Jean-Bapiste AunIOD, "L'ami de Saint-Bernard," Collectanea Cisterciensis r8 (1956), p. 88-99; Ann ProulX-LanG, "The Friendship between Peter the Venerable and Bernard of Clairvaux," in: Bernard of Clairvaux. Studies Presented to Dom Jean Leclercq, ed. Basil Pennington (Cistercian Studies Series, 23), Washington: Cistercian Publications, 1973, p. 35-53; McGuire, Friendship and Community, p. 253-58.

${ }^{16}$ Joseph LORTZ suggested the rhetorical nature of the amicitia language in his introduction to Bernhard von Clairvaux, Mönch und Mystiker. (Veröffentlichungen des Instituts für Europäische Geschichte Mainz, 6), Wiesbaden: F. Steiner, I955; Ambrogio M. PIAZZANI, "Un falso problema storiografico. Note a proposito della 'amicizia' tra Pietro il Venerabile di Cluny e Bernardo di Clairvaux," Bulletino dell'Istituto storico italiano per il medio evo e Archivio Muratoriano 89, (I980-I98I), p. 443487; Gillian KNIGHT, The Correspondence between Peter the Venerable and Bernard of Clairvaux (Church, Faith and Culture in the Medieval West, I), Burlington : Ashgate, 2002, especially p. 279-82, and id., "Uses and Abuses of amicitia: The Correspondence between Peter the Venerable and Hato of Troyes," Reading Medieval Studies 23 (1997), p. 35-67; here p. 36. ${ }^{17}$ Knight, Correspondence, p. 279-82 and "Uses and Abuses", p. 57.
} 
Peter and Bernard were 'really' friends, to why medieval monks would make reference to friendship with individuals they had never met. Knight offers a functional explanation to this question, suggesting that with Bernard and others, Peter used the discourse of friendship to broach contested topics while not harming common charity. ${ }^{\mathrm{I}}$ Her insistence on the literary nature of the relationship finds agreement in a larger body of scholarship highlighting that letters, not physical proximity, was a privileged space for the negotiation of monastic friendship. ${ }^{\text {I9 }}$

Knight's revision shows that the second inheritance from Clémencet -the definition of friendship-is problematic. For instance, earlier scholars conjectured where and when Peter and Bernard must have met to launch their friendship, assuming that personal contact must underlie friendship and thereby confusing a medieval term with their own modern conception. However, a growing body of scholarship (discussed briefly above) shows that medieval friendship had a distinct affective mode and ideation that was textual, public and political. By considering friendship merely as a literary artifact, Knight (like her scholarly predecessors) fails to distinguish what friendship was to Peter and his medieval audience, relying on modern theories of epistolarity to justify her approach. This approach, combined with an analysis of a small selection of letters, means that her work does not provide a satisfactory answer to how Peter understood the bond of friendship. Since there is considerable material to develop this subject, I believe it is worthwhile to investigate further the rhetorical claims that Peter makes about the nature of friendship.

Peter saw different kinds of friendship had different meanings and obligations. Ideally, it was an associative bond grounded in Christian love and charity and which demanded the performance of specific duties, but he also understood that not all friends were perfect. In Peter's writings we can see many references to mixed Classical and Christian traditions of friendship. Citations of Cicero, Sallust and Horace are blended with Scriptural injunctions or with the Christian thought of Gregory the Great or Augustine. ${ }^{20}$ Peter, however, was rarely concerned to speak about or to acknowledge the sources of his thought. His letters express many ideas which seem "Ciceronian," for example, but cannot be definitively traced to this author when identical ideas are articulated by others. Moreover, when Peter quoted from a source he would give the cited words a different meaning from their original context. For this reason, I have structured my study along thematic lines, in order to investigate the underlying consistency of his ideas without guessing at their precise intellectual genealogy. And Peter's sporadic comments do identify general and fundamental rules for friendship. There are true and false forms of

\footnotetext{
${ }^{\mathrm{I} 8}$ Knight here draws heavily upon the interpretation of friendship as a dispute resolution mechanism posited by Julian HASELDINE in his "Friendship and Rivalry: The Role of Amicitia in Twelfth-Century Monastic Relations," Journal of Ecclesiastical History 44 (I993), p. 390-4I4.

${ }^{19}$ This point is made in general by LeClercq (“L'amitié," p. 39I-4IO), it is highlighted with respect to Peter's letter collection by Giles Constable (Letters, II, p. I3-I4), and McGuire acknowledges it as well (Friendship and Community, p. 276). The idea has been further developed in reference to Peter the Venerable and Peter of Celle by HaSELDINE, "Friendship and Rivalry," p. 392-93.

${ }^{20}$ A library catalogue from Cluny notes the presence of several basic texts for the theory of friendship: Ms. 5OI was a copy of Cicero's De amicitia bound with Sallust's Bellum catalinae, ms. $53^{2}$ contained the works of Horace, ms. I74 Augustine’s Confessiones, ms. 48 Augustine's and Jerome's letters, and ms. II Gregory the Great's In Ezecheil; see the inventory printed in the Inventaire des Manuscrits de la Bibliothèque Nationale: Fonds de Cluni, ed. Léopold DELISLE, Paris : Imprimerie Nationale, I884, p. 337-373, The dating of this catalogue has been moved to during the abbacy of Hugh of Semur (IO49IIO9); on this, see Veronika VON BüREN, "Le grand catalogue de la bibliothèque de Cluny," in Le gouvernement d'Hugues de Semur à Cluny, Actes du colloque scientifique international, Cluny, septembre 1988, ed. Brigitte MaURICE, Cluny : I99O, p. 245-263, and id., "Le catalogue de la bibliothèque de Cluny reconstitué," Scriptorium 46 (I992), p. 256 -267.
} 
friendship. To be true, however, there must be a genuine virtuous love between like partners, it must be cultivated by words and deeds, and it must serve God. Each of these features deserves further explication.

\section{TRUE AND FALSE FrIENDSHIP}

Since Peter the Venerable was very concerned to emphasize his sincerity in friendship and to underscore what kind of friend he was not, he offers us an idea of the range of friendships he thought were possible. Fundamental to his thinking was the idea of a hierarchy of social ties: some relationships are called friendship, but are not "true friendship". Therefore it is important to begin with Peter's comments on negative friendship.

People who are excessively attracted to earthly pleasure are said to manifest a "friendship of the world". ${ }^{21}$ Peter lumps together monks who are unable to give up their memories of their former life with those who continue to display an excessive love of wealth, food and drink in this category. A second type of false friendship receives more extended condemnation. A "friend of Mammon", somewhat differently, is someone who acts as a friend to another, but does so out of a love for himself or his own personal gain. A friend of "Mammon" loves the rewards of his titular friendship, while his partner enjoys the flattery given to him. ${ }^{22}$ "Those who maintain a friendship for gain", Peter concludes, "are not to be honoured with the name of friends, but to be despised for the dishonor of their desires". ${ }^{23}$ They should be condemned since they have no loyalty or love for the person they call their friend, as he says in a letter to his "reverend and most beloved friend" Stephen, the former archbishop of Vienne:

I do not want to number among those friends who love [diligunt] only so long as they receive something, who love [amant] only so long as they look forward to something. I do not want to number among those who are called table companions, since, according to the one who said these words of wisdom, He who is a friend loves for all time and, as he also said, A friend is not known in good times, nor is an enemy hidden in the bad. ${ }^{24}$

This excerpt reproduces the tenor of Old Testament adages on amicitia about the importance of ceaseless loyalty and fidelity in friendship. The reference to "table companions" -friends who love only as long as they are well fed- is taken from Sirach 6.Io and the subsequent two quotations are, respectively, from Proverbs I7:I7 and Sirach $12.8 .{ }^{25}$ Peter alludes to these scriptural passages on more

\footnotetext{
${ }^{21}$ Letters, p. I63, ep. 53; mundi amicitia. Cf. James 4.4.

${ }^{22} \mathrm{~A}$ 'friend of Mammon' is described at length in ep. 6 (Letters, p. II-I3).

${ }^{23}$ Letters, p. I2, ep. 6 ; ... qui amicitiam propter pecuniam conseruant. Non sunt, non sunt tales amicorum nomine honorandi, sed cupidorum ignominia detestandi.

${ }^{24}$ Letters, p. 346, ep. I39; Non enim de illorum amicorum numero esse uolo, qui tam diu diligunt, quam diu accipiunt, qui tam diu amant, quam diu sperant. Nolo de illorum numero esse qui dicuntur socï mensae, quia secundum eius qui hoc dixit sapientis uerba, omni tempore diligit qui amicus est, et iuxta eundem, Non agnoscitur in bonis amicus, nec absconditur in malis inimicus. In the letter's salutation, Peter names Stephen, “reverando et carissimo amico." This passage provides a good example of how Peter uses "amo" and "diligo" interchangeably.

${ }^{25}$ The major treatments of friendship in the Old Testament are found in the book of Sirach, a text written ca. 2OO-I80 BCE which contains the author's distillation of contemporary Jewish wisdom in the face of the growing intrusion of Hellenism. The comments in Sirach on friendship share many themes and expressions with Greek treatments; see White, Friendship, p. 49$5^{2 .}$
} 
than one occasion, showing that it was a basic tenet that true friendship cannot arise from self-interest, but must be born from mutual love and trust. ${ }^{26}$

For Peter, friendship purely for personal gain in part transgresses proper ethical behaviour because it demands that one party flatter, lie and dissemble to the other. As Peter put in a letter to Henry, bishop of Winchester, "in truth, I would be a false friend if, speaking with a double heart, I conceal one thing in my mind and proffer another from my mouth". ${ }^{27}$ The mouth and heart or word and behaviour of a false friend are mutually opposed within himself, and the beliefs about the nature of the relationship are completely different between the two friends. As we will see emphasized by Peter, this divide of thoughts and the absence of a sincere mutual desire prevents any form of true friendship.

These statements show that Peter was well aware of the potential for hypocrisy and for a dissonance of word and behaviour. They demonstrate, moreover, that Peter's praise of "true" friendship (which is discussed below) was praise for an elite and idealized paradigm that often fell apart under the demands of the real world. Power plays by violent aristocrats, the world of ecclesiastical politics and even Peter's negotiations with the Cistercians provided opportunities to witness friends breaking with friends. ${ }^{28}$ As we have already seen above, memorable images of a topsy-turvy world in his letters to Hato of Troyes indicate Peter's anxiety over this possibility. ${ }^{29}$

A third type of false friendship -worse even than being a friend of Mammon- is betrayed friendship. Peter's condemns betrayal in friendship, declaring there is little worse than a friend withholding the duties of friendship. To Henry of Blois, bishop of Winchester, he comments, "I do not name an enemy one who does evil, but one refusing to do good, not one who shows their enmity by their deeds, but one withdrawing friendship's affect" ${ }^{30}$ Such betrayal is worse than mere enmity, he suggests, and a traitorous friend is the very example of evil. From such statements, we can likely see both Peter's awareness of broken friendships and an attempt to bolster an ideal -by demonizing the act of breaking with friends.

Despite the possibility of failure in friendship, Peter the Venerable saw the potential for it within every Christian. He did not demand social equality among friends since neither a change of circumstances (casuum permutatio) nor a difference in rank (honorum vicissitudo) hinders the fidelity between them. ${ }^{3 \mathrm{I}}$ When a friend changed from a monk to a bishop, for example, Peter felt no less of a friend to him. Gilo of Tusculum, a schismatic bishop and ex-Cluniac monk, was told by Peter that they remained friends despite this. ${ }^{32}$ A Cluniac monk owing Peter obedience could be a friend, as could a Cistercian abbot far removed from Peter's authority and even, perhaps, a Benedictine abbess. ${ }^{33}$ And

\footnotetext{
${ }^{26}$ Cf. ep. 66 and IоI.

${ }^{27}$ Letters, p. I49, ep. 49; Falsus uero amicus essem, si in corde et corde loquens aliud mente tegerem, aliud ore proferrem. Peter takes the expression “double hearted” from Ps. II.3; cf. its use in letters 5 (p. II), 36 (p. II7), 46 (p. I43), 49 (p. I49), IO2 (p. $263)$.

${ }^{28}$ Cf. especially Letters, ep. 28 and 39 .

${ }^{29}$ Peter's images of an inverted world, according to Gillian Knight, are veiled allusions to the social disorder which arose from the disunity of the papal schism; this interpretation, while possible, does not match Peter's explicit stated meaning; see her "Politics and Pastoral Care: Papal Schism in Some Letters of Peter the Venerable," Revue Bénédictine Io9 (i999), p. 359-390. ${ }^{30}$ Letters, p. I49, ep. 49; Hostem autem uoco, non mala inferentem, sed bona denegantem, non inimicitias effectu ostendentem, sed affectum amicitiae subtrahentem.

${ }^{3}$ Letters, p. I8, ep. 2.

$3^{2}$ Letters, p. I95, ep. 66.

${ }^{33}$ Peter of Poitiers (ep. 26, 58) and Theodard (ep. I4) are both acknowledged as Peter's friends and subordinate monks. Bernard of Clairvaux specifically, and all the Cistercian abbots generally are called friends (for Bernard, ep. III, I49, I8I, I92; for others, ep. 35, 36), and Heloise, abbess of the Paraclete is said by Peter to have sent "friendly words" (ep. II5).
} 
Peter did not limit his friendships to the clergy, counting lawyers and knights as well as kings and emperors as friends. ${ }^{34}$ True friendship, in Peter's conception therefore, was not a relationship possible only between wise men -as is often a component of Hellenistic thinking- but one between anyone recognizing friendship as a mutual and reciprocal bond.

\section{LOVE AND FRIENDSHIP}

As Peter understood it, true friendship is born from mutual love and attachment, just as the term friendship (amicitia) lexically derives from love (amo). This force of attraction is not unlike what we would today commonly refer to as our "affection" for close friends -in essence a form of non-libidinal desire. ${ }^{35}$ Peter's characterization of this love, however, was consistent with a general medieval trend differing significantly from our own in three ways. Firstly, he uses language we would largely consider to be romantic (i.e. indicative of sexual love). Peter follows contemporary epistolary modes in referring to his friends as "beloved" (carissime) and the first words of his letters usually express the depth of his love (amor). To Hato of Troyes he explicitly identifies friendship as a relationship which "knows only to love" $3^{6}$ and to countless other friends he underscores "our mutual love"; it is not uncommon for Peter to characterize friendship in physical terms, seeing it as "the great love with which I continue to embrace you". 37

A second point of difference from our current amatory modes is that friendship is considered a very strong -perhaps the strongest- form of social attachment. Peter, as was expected of a monk, likely considered friendship superior to sexual relationships. The strength of the bond is emphasized by repeated images of its binding nature. He underscores the idea of love's bondage to the knight Hugh Catula, a potential recruit for Cluny, when referring to "the love by which I am linked to you". To Theodard, a friend and Cluniac monk, Peter draws out this image, agonizing about "how heavy the shackle of love is [...]. It is stronger than any metal, heavier than any weight [...] I am held bound by this shackle, [...] I am bound by these chains wherever I go." ${ }^{8}$ The image that he presents suggests love's binding influence, which strongly allies two parties under its governance. What gives true friendship its powerful bond, we will see, lies in the nature of this attraction, which indicates a third divergence from modern norms of friendship.

The origin of love between friends is the soul's recognition of a kindred spirit in another. In this idea Peter follows a well established Stoic and Christian tradition. ${ }^{39}$ On one hand this idea could be interpreted as the general truism that "likes attract". As we explore in the following paragraphs, however, Peter envisaged this attraction of souls as a mystical offshoot of charity. Love between friends is not a superficial attraction, but a force intended by God to compel Christians towards the good and virtuous life.

\footnotetext{
${ }^{34}$ The lawyer Dulcian (ep. I9), the knight Hugh Catula (ep. 5I) and various kings (see especially ep. 9O, I3I and I62 to Roger II, king of Sicily).

${ }^{35}$ I borrow this term from Jaeger's study of medieval charismatic friendship, Ennobling Love, p. I6.

${ }^{36}$ Letters, p. 9, ep. 5 ; nichilque nisi diligere sciens.

${ }^{37}$ Letters, p. 42, ep. 22; mutuam dilectionem; p. 49, ep. 26; tam multus amor, quo te amplectebar.

${ }^{3}$ Letters, p. 2I, ep. I4; quam graue dilectionis uinculum [...]. Fortius hoc omni aere, grauius omni pondere [...]. Hac compede uinctus teneor, [...] hac cathena quocumque pergo uincior.

${ }^{39}$ According to Carolinne White (chp. 2), such ideas are expressed in Panetius's Moral duties, Cicero's On friendship and many Christian thinkers, such as Basil of Caeserea, Gregory Nazienzus, Paulinus of Nola, Jerome, Augustine and John Cassian.
} 
Unlike the false friend who is double-hearted, true friends possess a mutual single heart (simplex cor)..$^{4^{\mathrm{O}}}$ Peter frequently uses "unanimis amicus" as a descriptor of a true friend..$^{41}$ He calls Hato of Troyes, for instance, his unanimis amice in almost every letter, which literally translates as "friend sharing a soul". Borrowing the words of Horace, Peter also describes Hato as "half of my soul" without whose friendship Peter could not remain "a whole entity, but be wickedly divided in two' ${ }^{42}$ Peter the Venerable further explains how and why this unanimity was so desirable in a letter to the Cluniac monk Peter of Poitiers:

I considered you to be in accord [unanimis] with me in all things and I found in you what I contemplated in myself, such that I experienced in you -almost one and only- the definition of true friendship: both wanting and not wanting the same thing. Therefore,, nothing can please me which displeases you, nor can something displease me which you find pleasing; and according to what is read from another, it does not seem that there are two souls in two bodies, but rather that there is one soul belonging to two bodies. ${ }^{43}$

Supported by two authoritative citations, the former from Sallust and the latter a rephrasing of Augustine, Peter emphasizes a single message: that friends are united as fully and as intimately as if one being. This Classical definition of friendship is repeated when Peter's cites Cicero's On friendship in a letter to Hato of Troyes:

What union does a friend uphold, when he does not know that he is loved? How can that ancient definition of friendship still remain in force which states, friendship is nothing other than the accord of things divine and human conjoined with goodwill and charity? ${ }^{44}$

The answer to Peter's rhetorical question is that no friendship can endure without knowing the other's thoughts and feeling (i.e. consensio, the term which Peter takes from Cicero as the equivalent of unanimitas). The citation from Cicero emphasizes how this "accord" existing between friends is something greater and something more mystical than a meeting of minds, being instead a unity of temporal and divine things. If Peter took Cicero's definition to be true -as he seems to- then his references to Hato as "half my soul" are not hyperbole, but indications of his theoretical model.

\footnotetext{
${ }^{40}$ Letters, p. II, ep. 5. I translate simplex as single given the preponderance of this usage in Peter's letters, especially in ep. 28 to Bernard of Clairvaux, where Peter compares the twofold heart of Bernard (seeking divisiveness) to his own ability to see with the "single eye" of common charity.

${ }^{41}$ This expression appears throughout Peter's letters; see ep. 5, 7, I9, 22, 26, 29, 55, 58, 86, III, I66, I93.

${ }^{42}$ Letters, p. IO, ep. 5; animae dimidium meae and subsequently, me a te impie dimidiatum, non integrum remansisse. Peter cites Horace, Odes, I, iii, 1. 8.

${ }^{43}$ Letters, p. 183, ep. 58; Ita te in omnibus unanimen habebam ita quod in me aduertebam in te cognoscebam, ut in te uno et pene solo illam uerae amicitiae difinitionem expertus sim, "idem" scilicet "uelle, et idem nolle, ut nunquam michi potuerit placere quod tibi displicebat, nec displicere, quod tibi placebat" et iuxta quod dictum a quodam legitur, "non duobus corporibus duae sed una utrique corpori uideretur inesse anima."

${ }^{44}$ Letters, p. 2I7, ep. 8г; Quo enim pacto manet amicus, qui diligi se nescit? Aut quomodo stabit illa antiqua amicitiae diffinitio, qua dictum est quod "amicitia nichil sit aliud, quam divinarum humanarumque rerum cum benivolentia uel charitate consensio"? There are only minor differences from Cicero's text, cf. CiCERo, De senectute, De amicitia, De divinatione, trans. William FALCONER (Loeb Classical Library, I54), Cambridge, Massachusetts : Loeb, 1923; rpt. 200I, vi, 20, p. I3O-I3I.
} 
The idea of a harmony of the will between friends is the cornerstone of Peter's reception of Classical sources. But the Antique definitions of friendship had Christian relevance for Peter something he makes explicit when he recalls Sallust's definition of friendship (cited above) as "wanting and not wanting the same things":

If the passion of love could be so great among those ignorant of God [i.e. the Stoics] that they could say this not by fusing substances [substantias] but by uniting wills [uoluntates], how marvelous is it if the charity of God, which is diffused into the hearts of men by the Holy Spirit, unifies us in Him who makes each into one and who said to the Father about the disciples, so that they might be one, as we are. ${ }^{45}$

We see an essential characteristic of Christian friendship suggested. For Christian thinkers, friendship was radically changed after the incarnation of God and the descent of the Holy Spirit. ${ }^{6}$ What was a natural union of equal-minded individuals for the Stoics became for Peter a mystical association mediated by a Christian's reception of divine charity.

Charity forms the fundamental basis of Christian associative bonds in Peter's estimation. It is this form of fellowship that he refers to when he affirms a friendship founded on "Christ mutually uniting our hearts" in his letter to the cathedral chapter of Lyons. ${ }^{47}$ Or when referring to Christ as "He who loves us and who inspired you to love us [the ecclesia cluniacensis]" ${ }^{48}$ Or when calling the bond of friendship "a love derived from a supernal love" and "a vestige of eternal love". ${ }^{49}$ From such comments we can see that Peter considered friendship to depend on the bonds of love and charity between them.

Peter alludes to the role played by charity most explicitly to Geoffrey, Archbishop of Bordeaux. In this letter, he recounts how he had been meditating (universas animae latebras perscrutans) upon what it was that made Geoffrey such a "true and spiritual friend". ${ }^{\circ}$ His conclusion was that Geoffrey's "soul, spurning the terrestrial and cleaving to the celestial, his elegant manners, his singular prudence, his constancy in friendship and that Christ himself showed his presence in every seed of our mutual love, indivisibly conjoined him with me." ${ }^{\mathrm{I}}$ What Peter describes to Geoffrey is a mystical union born from their compatible love of and performance of virtue. Peter portrays their friendship as if it was involuntary and something divinely mandated. Friendship's foundation in charity therefore suggests that it is not a rational choice, but something inspired among the good.

What Peter indicates to Geoffrey is repeated in a number of letters which emphasize how the soul's recognition of a kindred spirit compels it to love. Personal contact, or intimacy, was unnecessary.

\footnotetext{
${ }^{45}$ Letters, p. I58, ep. 58; Quod si tantus innescientibus deum esse potuit amoris affectus, ut non substantias confudendo, sed uoluntates uniendo hoc dicere possent, quid mirum si "caritas dei" quae diffunditur "in cordibus hominum per spiritum sanctum" [Rom. 5.5] in eo nos uniuit "qui facit utraque unum, "[Ephes. 2.I4] quique patri de discipulis ait, "ut sint unum sicut et nos [John I7.II].

${ }^{46}$ WHITE, Christian Friendships, p. 53.

${ }^{47}$ Letters, p. 260, ep. IOо; Christo corda nostra ad inuicem uniente.

$4^{8}$ Letters, p. 27I, ep. Io8: qui dilexit nos, et qui uobis inspirauit diligere nos.

${ }^{49}$ Letters, p. II, ep. 5; amor ille a superno amore diriuatus and p. I76, ep. 55; uestigium amoris eterni.

$5^{\circ}$ Letters, p. 269, ep. Io6; spirituali et uero amico.

${ }^{5}$ Letters, p. 269, ep. Io6; The wording of this letter is somewhat winding, so I here offer greater contextualization: illum certe meum Burdagalensem archiepiscopu, quem non dignitas pontificalis, non sublimitas temporalis, michi in spiritulai et vero amico associauit, sed animus terrena spernens, caelestibus inhians, mores compti, prudentia singularis, amicitia constans, et uere Christus ipse ad universa mutui amoris primordia se medium exhibens, indivisibiliter coniunxit.
} 
His letter to Roger II, the king of Sicily, shows that even in an institutional context, this love was conceived as spiritually - conceding that reports of Roger's benevolent rule "first impelled me to love you and also urged me to admit you among the ranks of the greatest friends and benefactors of the Cluniac church" ${ }^{52}$ Peter admits the Cistercian monk Philip into his friendship since, as he writes, "your peaceful and benign manners recommended that I love you greatly". ${ }^{53}$ A telling example appears in Peter' correspondence with Bernard of Clairvaux, whom Peter called a friend long before they ever met. He explains why in his first letter to Bernard (ca. II27):

It was some time ago, my dearest brother -inhaling with a breath aromas fragrant with spiritual sweetness into the innermost part of my heart and beginning to love [diligere] you before I knew you, to venerate you before I regarded you- that I first wanted to see you, to embrace you, and to speak with you about spiritual exercises. ${ }^{54}$

The soul, we can see, lies at the heart of friendship. And by reaching out to like-minded individuals, the soul established a stable unified community. As Peter comments about Nicholas of Montiéramey in one of his last letters to Bernard of Clairvaux, "what greater proof of true friendship can there be than to love what a friend loves? I love him out of love for you, I love you out of love for him." ${ }^{55}$ Love, we can see, was expected to form a web of association that linked and strengthened Christian society.

Peter's explanatory framework for friendship was mystical, but we should be cautious about imagining that he naively imagined Christendom to be a society of friends. Charity explained how friendship was possible between people in a world of sin, but did not provide an indication of how people would behave. How people made use of the possibilities which charity/ friendship allowed, defined what kind of persons they were and determined their reward in the afterlife.

Since friendship was a bond between like-minded individuals, united through God and through an adherence to the virtuous life, friends were encircled by layers of responsibility to each other and to a larger "good" which they actively had to choose to uphold. Friends had an obligation to promote a life of virtue and to further the goals of Christendom together. This characteristic helps to understand better why breaking with friends was understood as such a bitter betrayal, since to break with friends meant a break from charity. A treacherous friend was therefore akin to a heretic, sundering the political and religious compact underlying Christendom.

\section{FOSTERING FRIENDSHIP}

Unlike the fleetingness of false friendships, long established friendships endured without end. As previously noted, many of Peter's images emphasize the strength of his relationship with his dearest

\footnotetext{
$5^{2}$ Letters, p. 23I, ep. 9O; Ista [...] ut inter magnos reges Romanos dico, Francos, Anglos, Hyspanos, maximos Cluniacensis aecclesiae amicos et benefactores, uos quoque admitterem coegerunt.

${ }^{53}$ Letters, p. 427, ep. 183; mores placidi et benigni, ut te multum diligerem suaserunt.

${ }^{54}$ Letters, p. 53, ep. 28; Malui quippe uiuo sermone secreta cordis mei tibi aperire, quam haec scedulae calamo percurrente committere. Sed multa terrarum intercapedo, multa negotiorum et tribulationum, nobis ingruentium amaritudo, hoc ne contingeret hucusque prohibuerunt. [...] Noui enim te eruditione saecularium, et quod est longe utilius scientia diuinarum litterarum instructum pariter et ornatum, [...] ut et aliorum indigentiam ipse diues permanens supplere, et de dubiis certam ferre sententiam ualeas.

${ }^{55}$ Letters, p. 423, ep. I8I; Et quae maior probation uerae amicitiae, quam amare quod amicus amat? Diligo eum causa tui, diligo te causa sui.
} 
friends: it is an unbreakable cord, a chain and fetters he will never remove or an indestructible shackle. ${ }^{5}$ A friend must be a safe harbour always offering refuge from the tumults of the world. ${ }^{57}$ But with these same correspondents, he also uses metaphors underscoring friendship's fluid nature. Friendship could be a rising and setting sun, a wine maturing over time, or a fire, sometimes burning bright, sometimes cooling to embers.

This last metaphor -used to warn Hato of Troyes about the necessity of a constant performance of friendship- is particularly evocative of how Peter views the inherent instability of friendship:

The proof of love is a demonstration in works. If there is a fire, it provides warmth. If it provides warmth, then it has not burned for long. If it has burned for some time, then soon it will burn itself out..$^{8}$

In friendship, Peter suggests, constant attention is needed. It demands careful stoking and knowing when to add more material for the fire. If too much time is taken between demonstrations of friendship, he implies, the passion of friendship will burn itself out. A later letter to Hato uses a related simile to underline how a friend's attention immediately revives an inactive relationship:

You have the manner of a bellows, my beloved, whose breath [spiritus] causes dying embers to ignite and then to erupt into enormous flames. By writing often, as if constantly blowing like a bellows, your spirit (not the airy, but the divine spirit as I see it) labours to rekindle the fire of my heart (certainly not deadened towards you!), and it also struggles to recall to its customary wordiness the breath [vapor] of my speech long hooded in silence. ${ }^{59}$

From this letter we see how Peter considers friendship to require a performance deeper than superficial words. A letter to Guarinus, the bishop of Amiens (ca. II43) confirms the necessity of proving that words are sincere when Peter praises him for correctly distinguishing, "between one kind of friend and another, between the true and the false, between those offering words and those showing deeds". ${ }^{60}$ But not all Peter's correspondents were as astute as Guarinus, forcing Peter at times to outline explicitly - as he does to Geoffrey, the bishop of Châlons-sur-Marne - the necessity of making a demonstration of friendship, "Words should be doubted if they are not preceded by deeds. A friendly soul does not buy friends with stark affection; it is customary to provide for friends less with the mouth and more from the heart, less with words and more through actions." ${ }^{\text {"6r }}$ Sincerity and evidence of true love, Peter underscores, is fundamental among friends.

\footnotetext{
${ }^{5}$ See ep. 5, 49, 55, and Io8.

${ }^{57}$ Letters, p. Io9, ep. 34 .

$5^{8}$ Letters, p. Io, ep. 5 ; Probatio dilectionis, exhibitio est operas. Si ignis est, calet. Si calet, non diu flammas continet. Si diu continuerit, mox ignis esse continuari.

${ }^{59}$ Letters, p. 223, ep. 86; Morem follies habes karissime, qui spiritu quo plenus est, emortuam fere scintillam ignescere, et in immensas quandoque flammas erumpere cogit. Sic spiritus tuus non ut ille aerius sed ut credo diuinus non quidem erga te emoruum ignem pectoris mei, sed diu silentio flando suscitare nititur, et ad uerba solita reuocare molitur.

${ }^{60}$ Letters, p. 27I, ep. Io8; [...] inter amicos et amicos, inter veros et falsos, inter dantes uerba et exhibentes opera.

${ }^{6 \mathrm{I}}$ Letters, p. 2I3, ep. 79; Dubitandum erat de uerbis, nisi ea opera praevenissent. Mercatus est amicus animus non nudo affectu amicos, quibus minus in ore, plus in corde, minus in uerbis, plus in rebus indulgere conueuit.
} 


\section{ACTIVE ProOf OF FRIENDSHIP}

Perhaps because it was so important to remain friends for reasons of charity and salvation, Peter identifies a very practical way of tending to and sustaining friendship: the demonstration of good intention (benivolentia) through the reciprocal performance of favours. Peter often cites benivolentia as a fundamental characteristic of friendship, but does little to convey its meaning. We have already noted a reference to benevolence when Peter cites Cicero's definition of friendship as an "accord of things divine and human conjoined with goodwill [benivolentia] and charity". Later in that same letter to Hato of Troyes, Peter calls attention to a second and related passage from Cicero's On friendship, "for what life can be a life worth living, as Ennius said, if it does not consist of the mutual goodwill [mutua benivolentia] of a friend". ${ }^{62}$ These two citations -the only two citations of Cicero in any of Peter's writings- suggest the importance of this theme, but unfortunately do little to explicate Peter's understanding of it. We do get a definition of benevolence -in the negative- from a letter to Peter of Poitiers, however. He chastizes this monk for a failure in friendship:

Never caring to reciprocate any return for our goodwill [benivolentia] -what I call a salubrious right of friendship- you seem to live for yourself, to take care for your affairs, but to slight those of others and -what is even worse- of friends. ${ }^{63}$

This passage suggests that the meaning of benivolentia is not too distant from its modern English equivalent. A lack of benevolence, as Peter puts it, is a lack of proper care given to others. But Peter seems to implicate benivolentia in two further expectations: firstly, that benevolence is part of a mutual reciprocal exchange, and secondly, that benevolence is linked to action.

A letter to Alberon, the bishop of Liège underlines the reciprocity of benevolence, which is presented as a product of gift-exchange:

Though we owe honor and also love through the bond of charity to all the churches of Christ, which in their numerousness make up the body of the one and catholic Church, we owe this to you especially [...] by whose love we are induced and by whose frequent bequests and great gifts we are abundantly incited to rebalance the mutual exchange of goodwill. $^{64}$

Likewise, a letter to Arnold of Lèvezon, archbishop of Narbonne, records Peter's appreciation for some unspecified favour, for which Peter now needed to render his "thanks for your benevolence" ${ }^{65}$ This

\footnotetext{
${ }^{62}$ Letters, p. 218, ep. 8I; Quae enim, ut Ennius ait, potest esse uita uitalis, quae non in amici mutual benivolentia consistit? The quotation is taken from Cicero's On friendship, vi, 22.

${ }^{63}$ Letters, p. 49, ep. 26; [C] um te michi semper adherere debere, tam multus amor quo te amplectebar, quam multa ultilitas qua te indigebam instanter commonerent subposui tamen uelle meum uoluntati tuae, praeposui salutem tuam necessitati meae, praetuli ocium tuum negotiis meis. Tu autem nullam huic nostrae beniuolentiae vicem reddere curans, quod saluo amicitiae priuilegio dixerim, uideris tibi uidere, tua curare, ea quae sunt aliorum et quod est deterius amicorum nilipendere.

${ }^{6}$ Letters, p. 229, ep. 89; Cum enim omnibus Christi aecclesïs quae numerositate sua unius et catholicae aecclesiae corpus perficiunt caritatis compagine honorem simul et amorem debeamus [...] hoc uobis debemus [...] quorum non solum amore prouocati, sed etiam frequentibus beneficïs et permaximis muneribus ad mutuam beniuolentiae uicissitudinem rependendam, magnifice inuitati sumus.

${ }^{65}$ Letters, p. 268, ep. I05; beniuolentiae uestrae gratias.
} 
bishop (whom Cluny had helped in the past) had assisted Peter in some episcopal negotiations, which suggests an ongoing relationship of favours. ${ }^{66}$ From these select comments, we can see that Peter envisages goodwill (benivolentia) as a product of both love and action. ${ }^{67}$ It is the good will and pleasant thoughts that arise following a demonstration of friendship and it is seemingly a way of feeling that characterizes strong friends. The more gifts are exchanged and the more love is expressed, the greater is the desire to reciprocate, and thus greater is the mutual bond between friends. Peter assimilates the terminology and theoretical obligations of amicitia, therefore, as a feature of medieval processes of giftgiving.

Ideally this process of exchange continued throughout one's life, since friendships should never end nor fade away. A friend's obligation to another does not even end upon one's mortal death, Peter believes, but continues afterwards. A letter to the Cluniac brothers of Saint-Martin-des-Champs about one of their recently deceased brethren describes how and why:

If indeed we were true friends, or are, we must show it now more when he is dead, than if he had lived. We should mourn with pious compassion his burial, we should follow his soul even more with hidden tears and prayers, so that to him whom we are not able anymore to show our feelings, we show it by smiling and rejoicing together, by praying and sacrificing and grieving together piously before God for his soul. ${ }^{68}$

The bond of friendship should be continued after death, since what better and more powerful friend can there be for a Christian than one in heaven.

\section{EXPRESSING CONTEMPLATIVE FRIENDSHIP}

While the mutual and reciprocal performance of favours underpins the practice of friendship, Peter saw other obligations as key to ensure its continuance. A friend should often speak to a friend to communicate his continued love and affection:

Neither according to Cicero, nor according to Gregory the Great are two or more persons able to unite with each other under the single goodwill or charity [of friendship] when they are unaware of the mutual affections of their souls, when they do not communicate their perceptions to each other, when they do not know whether they love or hate one another. ${ }^{69}$

\footnotetext{
${ }^{66}$ Cf. Letters, II, p. I69, note to 1.2.

${ }^{67}$ Further evidence for the exchange of benevolence can be found in the correspondence with Henry of Blois, bishop of Winchester. A letter to Henry (II36) records Peter's thanks for arranging a large gift from the King Stephen of England, but Peter specially emphasizes how generous Henry is with his goodwill (ep. 6o). His benevolence and generosity, Peter had affirmed in a previous letter, showed that he surpassed "all of Cluny's friends and benefactors" (Letters, p. I78, ep. $5^{6 \text {; super }}$ uniuersos amicos et benefactores nostros).

${ }^{68}$ Letters, p. 340, ep. I35; Sed si ueri amicifuimus, uel sumus, magis nunc mortuo quam si uiueret ostendamus. Deploremus pia compassione funus eius; prosequamur magis occultis lecrimis et precibus animam eius, ut cui iam affectum nostrum ostendere non possumus, conridendo uel collaetando; ostendamus orando, sacrificando, ac pie pro anima eius coram deo collacrimando. ${ }^{69}$ Letters, p. 2I7, ep. 81; Sed neque iuxta Tullium, neque iuxta Gregorium, conuenire in una beniuolentia uel caritate, duo uel plures poterunt, dum alternos animorum suorum affectus nesciunt, dum ad inuicem sensa sua sibi non communicant, dum utrum sese diligant aut odiant ignorant.
} 
What is basic in cultivating friendship, Peter emphasizes, is discussion. Speaking with a friend is a balm (remedium) for the soul, which "impatient and excited to proclaim itself in words, burns to speak and is reverent. It burns, so that it may reveal itself. It is reverent lest it be displeasing. It fears that if it keeps silent for long, it will seem strange or foreign".$^{7^{\circ}}$ If silence leads to the alienation of friends, then openness is implicated in the process of establishing unity between them.

When all intimacies are not revealed, or not often enough, a division could develop between friends' hearts and minds. But if friends keep in close contact, their interaction brings them together. To this end, Peter explains, "Since among friends all things are open [nuda], I endeavour not to conceal anything from you, to whom I propose to reveal everything -even the very intimate." Th The idea of friends expressing all their innermost secrets to each other was so basic, he suggests, and so foundational that the adage "everything is open among friends [...] is now commonly said". ${ }^{2}$

Conversation between friends was not just a means to an end, but is also one of the major pleasures of friendship for Peter. Directly quoting from Cicero's De amicitia, Peter asks Hato of Troyes, "What is sweeter than to have someone with whom you may dare to discuss anything, as if with your very self?" (De amicitia, vi, 22) ${ }^{73}$ He expects his friends to pursue forceful debate, contradiction and dissent, since the trust and love between them creates a forum for honest candor. In a letter to William, the bishop of Embrum ${ }^{74}$ and another to Geoffrey, the bishop of Chartres ${ }^{75}$, Peter makes reference to his duty as a friend to make known any grievances arising between them. He then precedes to rebuke, admonish and correct his correspondents for one or another failure in friendship. Only insults or prideful words spoken against a friend should be avoided, Peter suggests in an allusion to Sirach 22.26 when chastizing the insubordination of Ademar, a Cluniac abbot of Figeac (ca. II4O-II48). He refers to the proverb, "though you drew a sword against a friend, there may be a return to a friend," to emphasize that almost anything can be forgiven. ${ }^{76}$ In this letter, and by this allusion, Peter reminds a recalcitrant abbot that, despite a longstanding dispute, their friendship allows their differences to be bridged and overcome. Gillian Knight's analysis well demonstrates that Peter the Venerable's correspondence with Bernard of Clairvaux is dominated by this theme of how friendship overcomes superficial difference. ${ }^{77}$

In his letters to the Carthusians, Peter welcomes the opportunity to debate matters of spiritual and practical import. He portrays his correspondents as the "friends of Job", namely Eliphaz, Bildad and Zophar who came to comfort, console and debate with Job about the meaning of his sufferings.$^{8}$ The book of Job records their discussion and ends with Job praying for his friends who misguidedly offend

\footnotetext{
${ }^{70}$ Letters, p. 190, ep. 6o; Impatiens enim animus, et se uerbis indicare gestiens, loqui aestuat, et ueretur. Aestuat, ut se aperiat; ueretur ne displiceat. Timet, ne si multum taceat, alienus [...] ]uideatur.

${ }^{7}$ Letters, p. I49, ep. 49; quia inter amicos omnia nuda, nichil ultra illi tegere disposui, cui omnia etiam intima reuelare proposui.

$7^{2}$ Letters, p. I33, ep. 39; in context the line reads: quod iam uulgare factum est referam, si inter amicos omnia nuda, inter talem patrem et talem filium nulla secreta debuerunt esse uelata. In addition to these two uses, the expression and its sentiment are repeated in ep. $3^{6}$ and $\mathrm{IO} 2$.

${ }^{73}$ Letters, p. 2I8, ep. 8I; Quid dulcius, quam habere cum quo omnia audeas sic loqui ut tecum?"Cf. De amicitia, vi, 22.

${ }^{74}$ Letters, p. I8, ep. I2.

${ }^{75}$ Letters, p. 343-45, ep. I37.

${ }^{7}$ Letters, ep. 147, p. 362; Nec obstet itineri uestro querela mea, quia ut ait Solomon, est regressio ad amicum.

77 Though this idea dominates Knight's study, see especially chapters five and six of The Correspondence between Peter the Venerable and Bernard of Clairvaux, p. IOI-I54.

${ }^{8}$ Cf. Job 2.II-I3; the "friends of Job" are alluded to in letters 48 and I32 (to the Carthusians), as well as in letter I8I (to Bernard of Clairvaux).
} 
God when consoling him (Job. 42.7-IO). The friends of Job are emblematic of how Peter conceives friendly debate. It allows for discussion of any sort and it can survive - perhaps even thrives onexpressions of difference. It also has the goal of sharing a friend's tribulations, and making them easier to bear. Finally, since Job says prayers for his misguided friends, Peter suggests to his correspondents that the goal of all friendships is the service of the one God.

\section{EPISTOLARY FRIENDSHIP}

In the biblical account, Job's friends left their homes and traveled to console him. Unlike those three, Peter and his friends were often far removed from each other's physical presence. What was communicated in person, Peter believed, should continue to be expressed when apart. In the absence of presence, letters were the perfect substitute. We have seen this idea mentioned already in the letters to Hato of Troyes and Peter of Poitiers, but a letter to Henry of Blois, the bishop of Winchester specifically equates a friend's physical presence with messages sent at a distance. Peter laments his distance from Henry, but welcomes the exchange of "sincere love" in their correspondence which "the long journey and the wide ocean cannot prevent" ${ }^{79}$ The letter continues with a expression of his yearning to see Henry again:

This is what Solomon said about a friend: May your foot wear down his doorstep. ${ }^{80}$ Since I am not sufficient by myself, I take care to do this, God willing, with the help of my messengers. Recognize in me - if still it is also so with others - a custom of friendship such that the more a friend visits me, the more the passion of friendship grows in my heart. [...] The firm bond of love, an unbreakable chain, unifies us though we are far distant from each other. ${ }^{8}$

A similar sentiment is expressed to Peter the Venerable by Hato of Troyes who comments, "To use the words of a philosopher, neither physical distance nor temporal obstructions can fragment the rulership of love" ${ }^{82}$ The recitation of these topoic love phrases is the means to transmit emotion that could not be demonstrated in person. A letter to Gilo, the schismatic cardinalbishop of Tusculum helps us to understand how letters fulfill the obligations of friendship:

\footnotetext{
${ }^{79}$ Letters, p. I75, ep. 55; iter prolixum et [...] non poterit tamen oceanus minacifacie sua saltem amicabilium litterarum baiulos impedire.

${ }^{80}$ Peter here refers to Sirach 6.36. The passage, however, urges virtuous men to go often to someone they see as wise, not a friend. Perhaps this transposition is further proof for what was said above, that being a friend is evidence of upstanding Christian behaviour (e.g. wisdom). But its use here is most important for emphasizing how Peter inserts the statement as justification for the necessity of continually providing proof of love/ friendship.

${ }^{8 \mathrm{r}}$ Letters, p. I76, ep. 55; Sed et quod Salomon de amico ait, limen ostiorum eius exterat pes tuus, quia per me non ualeo, per meos deo donante implere curabo. Agnosco in me, si tamen et apud alios ita est, amicitiae consuetudinem, ut quanto magis me amicus frequentat, tanto magis in corde meo feruor ipsius amicitiae crescat. [...] Firmus ergo amoris nexus et indissolubilis cathena nos longe ab inuicem remotos uniat, nec eam ut puerili leuitate araneoarum telas, detrahentium loquacitas uentosa dirumpat.

${ }^{82}$ HATO OF TROYES, in Letters, p. 222, ep. 85; Vt uerbis utar philosophi principatum amoris locorum sapcia diuidere nequeunt, temporum incommoda separare non possunt. Hato's source has not been identified, though similar comments are present in JOHN CaSSIAN, Conferences, xvi, 3 but the sentiments expressed are generally quite common in friendship literature.
} 
Clearly, as I see it and perhaps also in accordance with the judgement of wise men, this is the entire purpose of true friendship: that a friend must communicate no less during his friend's good times than his bad and that a friend must feel his friend's misfortunes as if they were his own. ${ }^{83}$

It is significant, I believe, that he considers his letter to be an expression and an act of friendship. Communicating by letter fulfills the condition, for Peter, of standing by a friend in hard times.

Since sincere love can only truly be proven through the reciprocal performance of actions whether these be favours, debate or passionate letters- friendship is best the product of a long development. Peter emphasizes this point by repeating an image of longstanding friendship as aged wine, an allusion taken from Sirach (9.I5). Two linked letters written to the Cistercians Galcher and Philip compare their friendships to fine wines growing smoother as they mature. "The longer sincere love [continues]," Peter remarks to Philip, "the sweeter it is accustomed to be". ${ }^{4}$ This is an image fully elaborated in a letter to Hato of Troyes, whose friendship Peter praises as the sweetest of wines:

It is read in Solomon: Like new wine, let a new friendship mature and when it is sweet you may drink it. What does this mean? Take note, my beloved. It says this, which is commonly known. ${ }^{85}$ For wine, when it is fresh, certainly entices a taster by its newness, even though it is at first avoided due to the bitter sweetness of the stum; just as with the immature recklessness of the young, one repents the taste of the drink. Simultaneously smooth and caustic, it delights and disgusts; it is restorative when swallowed, but it is less pleasant when sipped. However, like an old man who has come to control his youthful passions, when new wine starts to age and to take on a smooth taste -the mild sweetness of maturity as it were- it not only becomes good, but is made enjoyable; it is drunk not only for good health, but also for pleasure. And there is no hint of a bite or sting in it. The heart of man rejoices -even literally, as Scripture suggests- and the onerous course of the mortal life is mitigated by the sweetness granted to him by the Creator of all things. So clearly, my beloved, so completely do I recognize Solomon’s text to be fulfilled in you. When you were a new friend, you were often indeed of such benefit; but never, even now when you are an old man, did you delight in frivolities. The friendship with you has grown old, not in terms of a weakening nor an agedness, but in the longness of time alone. $^{86}$

\footnotetext{
${ }^{8_{3}}$ Letters, p. 195, ep. 66; Hic plane, hic secundum meam et fortasse etiam secundum sapientum sententiam, hic inquam est integer uerae amiciae modus, si non mahis prosperis quam aduersis amici amicus communicate, si mala eius non minus quam propria sentiat.

${ }^{84}$ Letters, p. 427, ep. 183; Nam quanto sincerus amor prolixor, tanto suauior esse solet.

${ }^{85}$ This idea is also found in Cicero's On friendship, xix, 67 .

${ }^{86}$ Letters, p. 314-I5, ep. I2I; Legitur in Salomone: Vinum novum amicus novus ueterascat, et cum suauitate bibes illud. Quid est hoc? Attende, carissime. Hoc dicit quod cernitur. Vinum enim dum recens est, abjecta iam inutili musti dulcedine, bibentem quidem sui novitate allicit, sed uelut immatura iuuentutis uiolentia, sorbentis gustum compungit. Delectat et exasperat, ac salubre simul et mordax, interna haustu reficit, sed minus dum hauritur iucundat. At ubi uelut iuuenili feruore sedato, ueterascere incipit, et leni se sapore quasi miti senectutis suauitate condire, non solum bonum, sed et iocundum efficitur; non tantum ut salubre, sed et ut delectabile sumitur, et nihil in illo quod pungat uel mordeat, iam timetur. Laetificat, juxta Scripturam, etiam ad litteram, cor hominis et laboriosum cursum vitae mortalis, indita sibi a rerum conditore dulcedine consolatur. Sic plane charissime sic prorsus in te hoc Salomonicum uerbum impleri cognosco. Dum nouus amicus fuisti, sepe
} 
I cite this passage at length because it provides a representative example of Peter's literary monuments to friendship: not only does it explicitly lay out the delights and rewards of a longstanding and tested friendship, but it does so to praise a friend, thereby offering to Hato the sweet pleasure afforded by such relationships. Peter's praise, and his letter generally, becomes the means to ease Hato's burden, and therefore for Peter to act the faithful friend. Support is expressed through letters and through the love permeating the words.

\section{CONCLUSION}

Peter the Venerable's letter to Hato of Troyes provides a fitting conclusion for this brief study of the Cluniac discourse of friendship. It was written not long before Hato left his bishopric to permanently join Peter as a monk at Cluny - something Peter had hoped for in a lifetime of letters. ${ }^{87}$ What an effect knowing this must have had on the medieval audience of these letters! In reading Peter's words one is still touched nine and a half centuries after their writing by their openly expressed sentiments and by the image of two aging men taking solace in each other's words until their final reunion. I believe that this is the power and the intention of Peter's letters. The audience is shown the pleasure and delights of friendship and in reading about them is made to desire them. Whether or not there is real sentiment underlying these words cannot be answered. Peter's words, however, do answer another question. They reveal that the existence of a hierarchy with clear conditions which Peter used to distinguish and to publicize good and bad friends. Peter discriminates between true or false friends and outlines ways to evaluate the quality and quantity of a friend's favours. Why he does so, however, needs further study.

From a functional perspective, we can imagine that Peter, an abbot of a powerful monastic network, would have likely understood the value of his friendship to others, and may have been keen to outline how it could be won. Or, conversely, the Cluniac abbot sought to extend his fading influence when faced with Cistercian competition by appealing to self-serving discourses. When considering that medieval letters (and Peter's in particular) were sent not only to the recipients but were often publically circulated independently between monastic houses, there seems to be additional value in the discourse of friendship. In the court of public opinion, Peter could use his letters instrumentally: good friends were rewarded with renown and praise, while poor friends were humiliated. Whether praising or rebuking, Peter could remain at the centre of his community of friends, linked to powerful men across Christendom. He could also build up his own status and authority - showing himself to be superior to other monks in his conversance and observance of perfect friendship. With further study, I believe that Peter's letters will allow us to answer these questions.

quidem profuisti; sed nunquam, sicut nunc, quando iam senex es, delectasti. Consenuit tecum, non defectu, non aetate, sed sola uelut temporis antiquitate amicitia.

${ }^{87}$ Constable, Letters, II, p. I8I, note to ep. I2I. 